\title{
Unique Advantage of Socialist Political Development Road with Chinese Characteristics
}

\author{
Zhang Yang ${ }^{1}$; Zhang Liying ${ }^{2 *}$ \\ 1. School of Information Technology and Media, Beihua University, Jilin, Jilin 132013; \\ ${ }^{2 .}$ Law School, Beihua University, Jilin, Jilin 13200 \\ *Corresponding author
}

Keywords: Socialism with Chinese characteristics, Political development road, Unique advantage.

\begin{abstract}
China has made great achievements in political construction, among which, the most important is to have formed the socialist political development road with Chinese characteristics. With the formation of the socialist road, socialist political development road also comes into being and develops, and becomes a part of the socialist road with Chinese characteristics. In the initial stage of reform and open, the road had gradually taken shape, and its system was further established in later 30 years. On the basis of analysis and study on the historical background and guiding thought of socialist political development road with Chinese characteristics, the basic principle, development strategy and its advantages are discussed to provide certain references and suggestions for relevant researchers.
\end{abstract}

\section{Introduction}

Since reform and open, the Chinese society has improved constantly and its economy has also developed rapidly, and the social situation in China is changing significantly. The reform not only penetrates into the political field, but also go deep into the economy, specifically, an improved market economy is gradually established and China's comprehensive national power is persistently rising. It is clear that the direction of political development road is related to China's future and destiny to a large extent, and also affects economic development and people's immediate interests. Therefore, the socialist political development road with Chinese characteristics must closely combine with social development to make it have distinct characteristics of the times and thus better promote social economic development and enhance China's soft power.

\section{Concept of Socialist Political Development Road with Chinese Characteristics}

Socialist political development road with Chinese characteristics plays an important role in and is also a significant part of the socialist development road with Chinese characteristics. The construction and development of socialist political development road with characteristics is the vital guarantee of China's socialist modernization. In addition, socialist political development with Chinese characteristics is a crucial content of the important thought of Three Represents. Jiang Zemin proposed the concept of "political development road" in the report of the 16th Party Congress. He pointed out that "the Communist Party of China and Chinese people are confident in their choice of political development road and will unswervingly push forward the socialist political construction with Chinese characteristics". On the Second Plenary Sessions of 16th Central Committee of the Communist Party of China, Hu Jintao proposed the significant topic that "we must always adhere to the socialist political development road with Chinese characteristics". In the report of 17th CPC National Congress, Hu Jintao proposed that " we should persevere in socialist political development road with Chinese characteristics, adhere to the organic unification of leadership of the party, people's master status in the country and managing state affairs according to law, uphold and improve the system of people's congress, system of multi-party cooperation and 
political consultations led by CCP, the system of regional national autonomy and the system of community level self-governance, constantly promote the self-improvement and development of socialist political system, and advance the exploration of socialist political development road with Chinese characteristics to a new stage.

Since reform and open, the development road for China to realize a specific goal is socialist political development road with Chinese characteristics, which means the road is of great importance to the realization of some goals of China. The Community Party of China has integrated the ideal of Marxism and China's fundamental realities and social development status in the whole social development process, and established a more perfect market economic system. Adhering to the leadership of CCP and the socialist road with Chinese characteristics, and developing the political road with distinct Chinese characteristics can promote socialist modernization, enable people to master their country, and drive the further development of market economy. China's political development road has obvious difference with the political development road of other countries, and is different with the road walked by the CCP in the early stage. Besides, it is a road that accords with China's national situation and actual development of China.

\section{Unique advantages of socialist political development road with Chinese characteristics}

\section{(1) Socialist political development road with Chinese characteristics can promote the development of political party}

With China's political development, the political party also develops and occupies a more and more important position in the political arena, becomes a significant part of China's modern democracy, and plays a vital role. China has a long history, and some traditional thoughts are ingrained and can't be changed really within a short time, therefore, China now is transmitting from tradition to modern. In the development process of democracy, economic development and promotion of national strength are necessary as a powerful support, and meanwhile the management and promotion by a strong governing party are in urgent need. The development of a governing party is the demand and law of national political development, and also the special requirement proposed by a realistic society. In the history of China, the CPC developed with the China's political and cultural development step by step, and it was arduous for it to walk to the political arena. Besides, its leading role in China's modernization was established through long-term struggling hard amid difficulties, therefore, the ruling status of the CCP must be firm.

The development of China's democracy not only depends on the improvement of China's comprehensive national power and economic growth, but is based on the leading and promotion of the CCP. In China's modernization, the stable political system lies on the capability of the ruling party while the power is mainly from the support of the ordinary people of the society. The water that bears the boat is the same that swallows it up. The strength of the masses is powerful, therefore, only the people's life is guaranteed and the masses consciously support the leadership of the party, can the party better manage the country. As a result, the influence of socialist political development road with Chinese characteristics is of great importance and able to promote the development of the ruling party, which plays an important role in China's social stability.

\section{(2) Socialist political development road with Chinese characteristics can advance political development through political system reform}

At the beginning of reform and open, socialist political development road with Chinese characteristics has included the reform of the political system into the reform scope to be an important method to promote political development. Due to the effect of Soviet mode, the earlier political system had many problems and was lagging, and unable to adapt to the development of the times, therefore, socialist political development road with Chinese characteristics changes the status with system reform to further promote political development. Therefore, the CCP should actively mobilize the enthusiasm of the masses and make them participate in the political development. In China, guaranteeing the democracy within the party is conducive to promoting the development of people's democracy to some extent which generates a counterforce to the democracy within the party. As a result, in essence, political system is to improve the socialist political system, guarantee 
the coordinative development of politics and economy.

\section{Conclusions}

In the process of practicing socialist political development with Chinese characteristics, the CCP respects the creative spirit of the masses, and guides the masses to create a lot of new modes adaptive to China's socialist democracy development in practice, and there will be more and more flexible and pragmatic new modes in the construction of socialist democracy with Chinese characteristics.

\section{References}

[1] Wu Chenglin. On the advantages and characteristics of the political development of socialism with Chinese characteristics [J]. Journal of Social Science of Jiamusi University, 2015, (6).

[2] Chen Jing. The socialist political development road and the United Front with Chinese characteristics [J]. Journal of Heilongjiang Institute of socialism, 2008, (3).

[3] Mei Rongzheng. Unswervingly follow the road of socialist political development with Chinese characteristics [J]. Journal of Guizhou Normal University (SOCIAL SCIENCES EDITION), 2014 (4).

[4] Zheng Kaixuan. Research on the basic characteristics of the road of socialism with Chinese characteristics. [D]. Northeast Normal University. 2016(3).

[5] Xu Yaotong. The new development of political construction of socialism with Chinese characteristics since eighteen. [J]. Party and government research. 2017(9).

[6] Xie Qingsong. "Ma soul zhong ti xi yong" Political Implication -- Chinese socialist political road, theory, system basic paradigm [J]. Journal of Yunnan Administration Colleg. 2017(1). 